Article

\title{
The Evolution and Adaptive Governance of the 22@ Innovation District in Barcelona
}

\author{
Alberto Gianoli 1,*(D) and Riccardo Palazzolo Henkes ${ }^{2}$ \\ 1 Institute for Housing and Urban Development Studies, Erasmus University Rotterdam, 3000BX Rotterdam, \\ The Netherlands \\ 2 everis, 08028 Barcelona, Spain; riccardo.palazzolo.henkes@everis.com \\ * Correspondence: gianoli@ihs.nl
}

Received: 5 March 2020; Accepted: 8 April 2020; Published: 11 April 2020

\begin{abstract}
The paper analyzes the prominent 22@ Innovation District project, which was initiated at the beginning of the 2000s by the city of Barcelona to regenerate part of the Poblenou district, a former industrial area. The goal was to create an innovation district able to generate economic activity and employment by focusing on knowledge economy and new technologies. The innovative features of the project emphasize the uncertainty and the need to adapt to new technologies and their economic and social influence in urban regeneration projects. The paper uses the adaptive governance framework to analyze how the dynamic process of urban regeneration and creation of an innovation district has been able to adapt to internal and external changes of political, economic and technological nature. Adaptive governance has been conceptualized by focusing on three key aspects (i.e., level of complexity, conflict and uncertainty) and three main actions (i.e., anticipate, learn and adapt) that have been considered in the case study. These elements emphasize the need for bridging organizations that are able to work cross-level and cross-scale. The article shows the suitability of adaptive governance systems in urban regeneration projects, aiming to combine top-down and bottom-up initiatives within a comprehensive strategy.
\end{abstract}

Keywords: urban regeneration; innovation districts; adaptive governance; Barcelona

\section{Introduction}

Cities around the world need to regenerate former productive areas no longer integrated within the economic milieu. Old factories and obsolete infrastructures face the consequences derived from economic and political changes, as well as new technological developments. However, these areas and assets still have important economic and societal potential, especially when they are located in strategic positions within the city [1]. Regenerating them may provide a concrete opportunity to promote and foster economic growth and generate employment, or to increase the housing stock and improve the quality of life of the citizens [2]. Urban regeneration aims at fostering a lasting improvement in the economic, social, physical and environmental condition of an urban area that has undergone a structural change [3]. The regeneration of districts and areas of the city implies not only a restoration to a previous status but something beyond; it entails the creation of spaces more attractive, socially inclusive and environmentally sustainable [4]. Boston, London, Manchester, Medellin and Montreal have adopted the strategy of creating an innovation district as a course of action that combines the regeneration of an area with the promotion of a knowledge-based economic activities. It offers a solution to two main problems: underused or abandoned areas in the urban continuum and the lack of available land for large projects within the urban area. These innovation districts are characterized by the cooperation between the public and the private sectors as well as universities and research institutes, working together to create synergies to stimulate economic growth and social cohesion [5]. 
The 22@ Innovation District (hereinafter 22@) is the project that the city of Barcelona started to implement in 2000 and it is still implementing and adapting in order to respond to the new context and needs of the city. Barcelona has promoted the vision of becoming a "city of knowledge" [6] (pp. 111-124) and the creation of the 22@ has been its main strategy. The experience of 22@ can be analyzed through the lenses of the "smart city" discourse according to which cities may aim at achieving sustainable development by harnessing new technologies. However, the idea of the smart city should not be limited to technological aspects but also entail innovative governance approaches able to steer urban development processes under uncertain conditions. On this basis a conceptual connection can be established between the notion of smart city and the concept of adaptive governance. The creation of an innovation district requires a strong and long-term commitment of all the key stakeholders involved. The complexity of the strategy and the uncertainty towards the future implies a certain degree of flexibility and adaptability in order to react to any possible shocks. There are internal factors (e.g., change of actors, new organizational structures) and external factors (e.g., economic crises, political shifts, new technologies) that inevitably change the context within the processes taking place. As a result, the governance system that supports the creation of an innovation district has to be able to adapt to changing circumstances. Against this background, the article aims to analyze the evolution of 22@, including the complexity and uncertainty that characterized its development during the period 2000-2018, and assesses how the economic, political and technological changes were dealt with through the adoption of an adaptive governance model. The novelty of the article lies in the use of the adaptive governance framework in order to analyze and explain the different development phases of the innovation district 22@. Coordination across actors, cooperation between stakeholders, leadership capacity and knowledge-based decision-making are all key dimensions of adaptive governance and combined constitute a relevant conceptual framework that allows to shed light on how an innovation district may be able to dynamically respond to change pressures brought about by internal and external factors. Urban regeneration projects are characterized by a high degree of uncertainty, conflict, and complexity, as they are usually developed within a long-term perspective where situations of asymmetry of information and power among actors are frequent. The paper argues that adaptive governance principles can offer solutions to the challenges inherent in urban regeneration projects.

\section{Innovation Districts, Adaptability, and Adaptive Governance}

Innovation districts can be defined as compact mixed-use developments where public sector institutions and private businesses cluster spatially with business incubators and accelerators [7]. The key characteristic of an innovation district is the complex interaction between business activities, economic development, urban planning and innovation. It is important to highlight the urbanistic feature beyond the economic aspects that tries to pursue a lasting environmental, social and infrastructural impact [7]. Furthermore, innovation districts promote the proximity of workers, companies, universities and research labs based on cooperation, collaboration and the success of sharing ideas and creativity [8]. The concept of innovation district derives from the evolution of the notion of industrial district first developed by Alfred Marshall in the 1920s [9] and the concept of flexible specialization by [10]. The first ones were characterized by the importance of the location of complementary industries for the generation of synergies within the city [11] (pp. 159-178), whereas the second ones were mainly based outside of urban areas and had the objective of increasing the commercialization of academic research [12]. There are different models of innovation districts according to the main actor and the dynamics that generated its creation [7]. The first model is the "Anchor plus", where an extended area with mixed land use surrounds an anchor institution with businesses and entrepreneurs involved in innovation activities. The main actor attracts and promotes all the changes, using its financial or potential resources together with a convincing narrative. The second one is the "Re-imagined urban areas", with an industrial area transformed physically and economically to promote innovation-based economic growth. The leading force in this model is 
the purpose of improving an area that has a high potential, either for its strategic position or for its underused assets. The third model is the "Urbanized science parks", the case of an isolated innovation center that is urbanized by the addition of housing and new facilities, incrementing the densification and the attractiveness of the area for investors. The fourth one is the "Organic generation", when small and medium companies locate in the same area and gradually create a network, which is acknowledged at a later stage as an innovation district.

Innovation districts are characterized by five crucial elements that are relevant in the regeneration of urban areas:

- The first element is the structure of the main actors implicated in the creation of innovation districts: the public sector, private sector and universities constitute the so-called Triple Helix approach [13]. This governance concept has evolved including the concepts of hybrid actors or adding the users of innovation/citizens as the fourth element in a Quadruple Helix approach [14].

- The second element is the diversified function played by economic clusters, where private companies concentrate and cooperate with research centers, stimulating positive synergies [5].

- The third element is related to the generation of economic development. In order to promote innovation, it is of fundamental importance to invest in research and knowledge-based activities. Based on the principle of flexible specialization [15] (pp. 15-27), this approach is characterized by the role played by the labor force and technology as crucial assets able to adapt to ongoing changes [16].

- The fourth element concerns the specific role played by technology. The technological sector in innovation districts stimulates both knowledge creation and technology-based innovation. Living Labs and Smart Cities are the embodiment of these dynamics.

- The fifth element is the role played by the so-called creative class in the development of innovation districts. The attraction of talented workers is crucial for innovation districts and requires the provision of a high standard of quality of life. Innovation districts need to balance the needs of skilled workers and competitive companies [17,18].

Based on the above it can be argued that innovation districts are compact areas with mixed-used land development and are characterized by close networking between public institutions, clusters of technologically oriented businesses and a dynamic milieu of startups, business incubators and accelerators. Innovation districts are unique because of their focus on economic development, urban planning and technological innovation. As an urban development strategy, the creation of innovation districts may address the multiple needs of urban regeneration, business creation and innovation promotion. In order to thrive, innovation districts need to promote economic, physical and networking assets and this can be better achieved through ad-hoc governance arrangements characterized by flexibility and capacity to adapt to ongoing changes.

Adaptive governance is a concept that derives from the analysis of environmental and socio-ecological systems. Based on the assumption that the external context is constantly changing and knowledge is incomplete and unevenly distributed, adaptive governance allows decision-makers and stakeholders to respond to institutional, social and environmental changes [19]. Although some principles of adaptive governance have already been applied in studies related to large infrastructure projects [20] (pp. 999-1018) and technology innovation [21] (pp. 1-5), the concept has never been used to analyze the complex processes of urban regeneration. Following [21] (pp. 1-5), adaptive governance can be defined as an approach suitable to analyze complex societal issues characterized by a high degree of uncertainty and where multiple stakeholders have diverging interests and possibly competing agendas.

The need for new governance approaches derives from the multi-level and multi-scale character of societal, economic and environmental challenges [22]. The interactions considered by adaptive governance approaches are both cross-level and cross-scale, where cross-level interactions refer to interactions between levels belonging to the same scale (e.g., the national level, regional level and 
municipal level of government), whereas cross-level refers to interactions between different scales (e.g., the ecological and political scales). Bridging organizations play an important role in the reduction of conflict, increasing the cooperation among different actors in situations of cross-scale and cross-level interactions [23]. Closely related to adaptive governance is the notion of complex adaptive systems, which can be defined as dynamic systems able to adapt and evolve within a changing context [24]. Three fundamental elements characterize complex adaptive systems: evolution, aggregate behavior and anticipation. In order to evolve it is important to learn about the context and adapt to it [25]. This process highlights the importance of the knowledge of the context over time. In our case, it can be simplified as the communication among actors and how the existing relationships change over time. The aggregate behavior can be exemplified with the generation of positive externalities and synergies due to the aggregation of interests and collaboration of actors. Complex adaptive system theory provides insights on how this value is generated.

Adaptive governance systems are based on three interrelated and sequential courses of actions [21] (pp. 1-5): anticipation, learning and adaptation. The order of actions suggests their practical implementation, since anticipation implies actions to apply ex-ante and adaptation implies actions to perform ex-post, while learning is a transversal process essential for the other two. A more empirical approach has been used by [26] (pp. 174-184) in order to identify methodologies that can support the implementation of successful adaptive governance processes and dynamics. These methodologies comprise the following: collaboration across actors and scales; effective coordination between stakeholders and levels; strengthening social capital; community empowerment and engagement; capacity development; linking knowledge and decision-making through data collection and monitoring; and promoting leadership.

The analysis makes use of the following theoretical framework (Figure 1) to analyze how the interplay of external and internal factors in the political, economic and technological spheres, moderated by flexibility and adaptability, which are key characteristics of an adaptive governance model, have influenced the development of 22@. Political, economic and technological changes are considered as the exogenous factors in the framework, and they have a combined effect on the development process and dynamics of 22@. This effect manifests itself over different spheres including physical integration, cluster generation, promotion of economic activities, housing and green areas as well as smart infrastructure. The analysis explores how the adoption of an adaptive governance model in 22@ has influenced and shaped the way the innovation district has developed over the years also as a reaction to the exogenous factors. As will be demonstrated, the ability of the district to deal with a complex and changing context heavily depends upon specific adaptive governance structures and particularly processes.

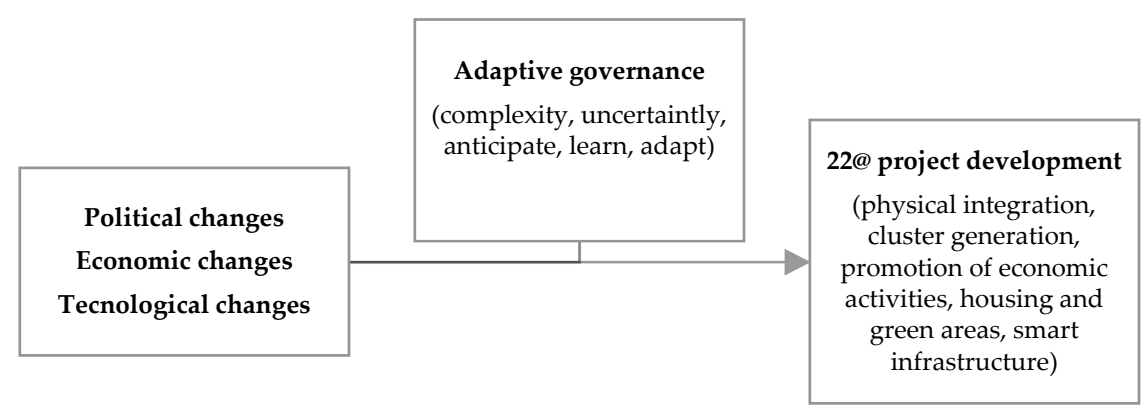

Figure 1. Theoretical framework.

After the methodological section, the paper describes the 22@ regeneration model within the context of the wider regeneration strategies adopted in Barcelona. It then analyses the impact of political, economic and technological changes and how these have influenced the development of $22 @$ through the moderating effect of adaptive governance. The paper concludes with some general reflections on the relationship between innovation districts and adaptive governance. 


\section{Research Methodology}

A single case study is used as the most appropriate research strategy in order to explain the evolution of an urban regeneration process within its context and considering different variables. The case study approach allows to better comprehend the complexity of a phenomenon and in particular the complex relationships between different variables, actors and events [27]. Primary data were collected mainly through semi-structured interviews with experts in different fields that were selected through a purposive sample. A purposive sample approach was used in order to select key actors and stakeholders that had been directly involved in the development of 22@ or that had carried out studies on the area and process. This allowed to triangulate and validate the information derived from the analysis of the relevant secondary sources reviewed. Overall, twenty interviews were carried out with key informants comprising former mayors of Barcelona, public managers, academics and researchers, and community representatives. The interviews followed a specific structure but also allowed flexibility based on each interviewee's role in the project, their knowledge and expertise. All interviews covered three core areas in line with the external sectors analyzed (i.e., political, economic and technological) as well as specific questions on adaptive processes. Detailed interview guidelines can be found in Appendix A. Secondary data were collected from municipal reports and academic studies. The analysis of the effect of the exogenous factors on the development path of 22@, moderated by the adoption of an adaptive governance framework, has been derived from the combination and triangulation of primary and secondary sources covering the period since the initial phases of the establishment of the innovation district in Barcelona.

\section{22@ and the Barcelona Regeneration Model}

22@ was initiated at the beginning of the 2000s by the city of Barcelona with the aim to regenerate the eastern part of the city, creating a new centrality and urban continuum. The project was specifically directed at regenerating part of the Poblenou district, a former industrial area that became obsolete due to the transformation of the economic activity of the city. The goal of the project was to create an innovation district able to generate economic activity and employment by focusing on the knowledge economy and new technologies. The implementation of 22@ had specific objectives related to the transformation of the physical, economic and social dimensions, such as physical integration, stimulation of economic activity, clusters generation, promotion of the district image and branding, and new housing and green areas development. Regarding the physical transformation, the main objective of the project was to create a compact and flexible district with high density, modern infrastructure networks and mixed uses. Given the limited land availability within the city boundaries, the achievement of high density and the efficient use of available land resources was a necessary precondition (Figures 2 and 3 ). Besides the conventional utilities (roads, water and electricity distribution and sewers), the district was equipped with fiber optics, a connection to pneumatic waste and spaces for climate control systems. These elements created the optimal conditions for the development of Urban Lab projects, which were delimited areas allowing companies to test new technologies, later replicated in other areas of the city. These initiatives can be considered as a clear attempt to promote technology-based innovations and characterize the development of $22 @$ as a smart city district. The focus on networked infrastructure, innovation and business-led urban development and regeneration are key elements of the smart city discourse.

As per the economic transformation, the creation of clusters was the main strategy promoted in order to generate synergies and attract different stakeholders from specific sectors. The clusters strategy was crucial to promote a knowledge-based approach to economic development in the district, with the public sector, private companies and universities as partners. Creating clusters meant not only to integrate companies and activities based on a business rationale but also integrating these companies and activities in the city transformation and relating them to the daily lives of the district. This strategy started in 2004, once the physical transformation had been achieved and the municipal company realized the importance of promoting the economic activity of the district by creating synergies among 
the new companies. The four original clusters were Media, ICT, Energy and Medical Technologies, with the addition of the Design cluster due to the competitiveness of the city in this sector.

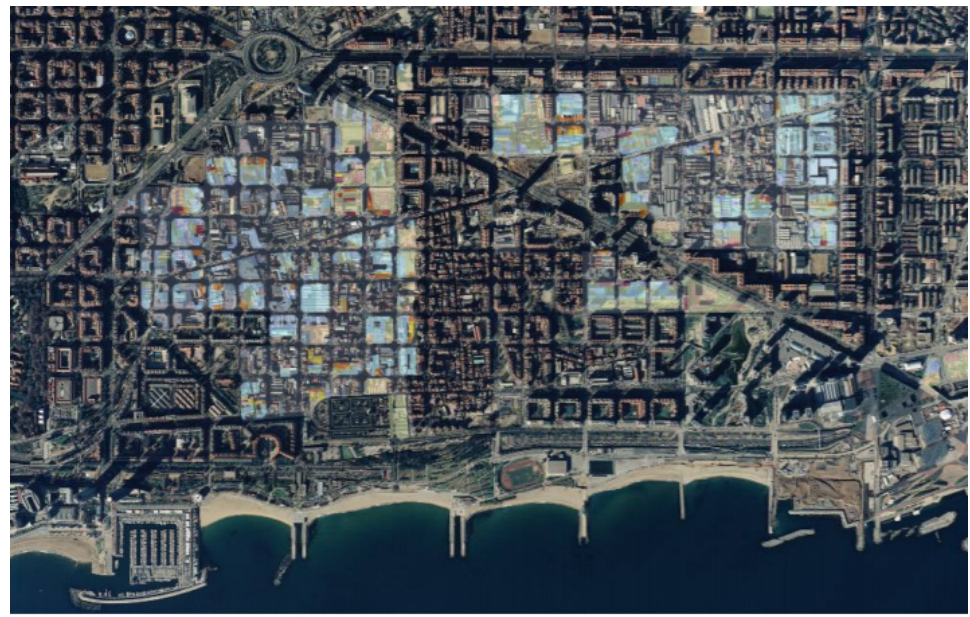

Figure 2. Satellite image of the 22@ district (source: Municipality of Barcelona).

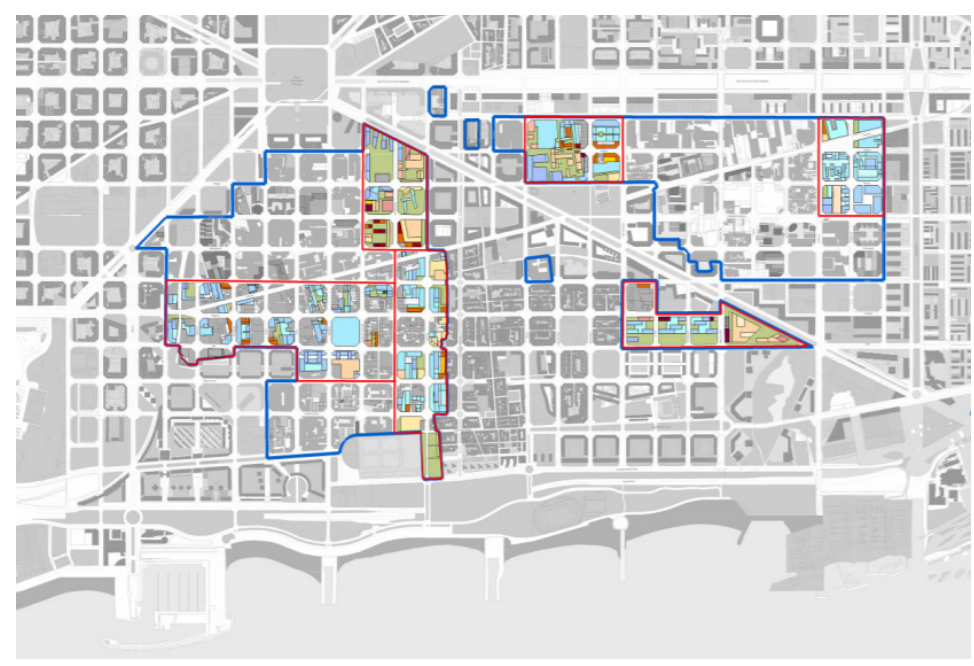

Figure 3. Development areas of the 22@ district (blue line: overall perimeter; red line: business and other non-residential areas) (source: Municipality of Barcelona).

The social transformation was based on the integration of this part of the city within the urban continuum by improving the public transport system, increasing the offer of social housing, obtaining employment opportunities for its residents (both qualified and non-qualified) and promoting the generation of business networks. The overall improvement of the quality of life of its residents is the main social transformation obtained through relevant physical and economic transformations. The idea to promote an innovation district in Barcelona originated from two concepts developed at the end of the 1990s regarding the future of Barcelona: City of Knowledge and Technological City. The first concept was promoted by Prof. Trullén and his studies about the importance of knowledge in the new economy [28] (p. 1985) and the consequent municipal strategy "Barcelona, City of Knowledge" endorsed by the former mayor Joan Clos (Barceló 2007). The key idea was that new technologies had made information cheaper and more widely available. As a result, knowledge is the element that differentiates and generates additional value, increasing economic competitiveness and also social equity [28]. The second concept was put forward by Miquel Barceló (founder and future president of the municipal company 22 Arroba BCN SA) and Antoni Oliva (future secretary of 22@ Network Association), which argued that new technologies allowed industrial development initiatives to be 
part of the urban ecosystem of Barcelona. This was of course an industry that needed less space than the traditional one; it was environmentally friendly and only required good infrastructures and a close connection with the centers of information and knowledge.

To better understand the role and significance of 22@ it is important to contextualize it into the wider regeneration strategies followed by the municipality of Barcelona since the 1980s. There are three main periods of regeneration initiatives in Barcelona [29]:

- $\quad$ 1980-1986: Small scale regeneration approach focusing on public spaces such as squares, streets, and parks;

- 1986-1992: Larger scale regeneration approach focused on the seafront, sports areas, district equipment and improvement of the road system in preparation for the 1992Olympic Games;

- 1992-2004: Metropolitan scale regeneration approach based on large infrastructure developments and strategic areas.

The Barcelona Model of urban regeneration is famous worldwide and has been crucial for the rebirth and renewal of the city and its city branding. This model has some specific characteristics that have defined the success of the regeneration projects undertaken over the past decades [29] (pp. 355-369):

- Use of major events;

- Design of specific areas of the city;

- Development of a relational and inclusive model of management;

- Creation of autonomous public agencies;

- Territorial decentralization;

- Involvement of citizens in public decision-making.

The 22@ presents most of these characteristics with some relevant exceptions: firstly, no major event led the transformation and, secondly, it was not characterized by citizen involvement. In fact, a strong need to regenerate the area by keeping its economic nature led the project and the regeneration was suggested by the need of competitiveness in attracting companies and investors. From an organizational point of view, two actors have played a very important role in the development of the Innovation District 22@ and in its capacity to adapt to external changes: the municipal company 22 Arroba BCN SA and the 22@ Network. The municipal company 22 Arroba BCN SA has been instrumental in the development of the project. Among others, the company was responsible for the following key functions and activities:

- Planning, promotion, design, construction and management of infrastructure projects, urban services and public spaces;

- Economic promotion of the district at the national and international level;

- Support the establishment of new companies in the technological and communication sector.

The company was the pivotal reference point for the different aspects of the transformation. It comprised three main departments (i.e., urban planning, management and infrastructures) and in a second phase these were supplemented by economic promotion and marketing. This integrated organizational arrangement promoted efficient and effective decision-making. This experience shows the importance of an integrated approach to urban transformation, focusing on physical, economic and social aspects, as well as the relevance of making use of a multidisciplinary team in charge of urban planning and economic promotion. The company worked as a bridging organization between different levels and actors, being an element of continuity within an ever-changing environment. The 22@ Network, established in 2004 by the president of the 22 Arroba BCN SA, Miquel Barceló, is a business association whose members are the companies and institutions located in 22@. Its main remit is to support the economic development of the district. It represents the voice of the business sector at the district level and it was created to be a partner of the 22 Arroba BCN SA. After the dismantling of the municipal company, 22@ Networks is considered as the successor, although with more limited powers. 


\section{Results: 22@ and Adaptive Governance}

This section describes how the project evolved to achieve its objectives through an adaptive governance system against external factors that have influenced its development. Following the concepts explained in the previous sections, the three main categories of actors justify the categorization of factors selected: political factors (public sector/municipal company), economic factors (private sector) and technological factors (universities and research centers, especially in clusters generation). The main external factors identified that have influenced the implementation of the project are therefore municipal elections (2006, July 2011, June 2015), the financial crisis and the role of public and private investments that started in 2008 and the shift from "City of Knowledge" to "Smart City". The high level of adaptability of the project is a crucial element that can be found in the different aspects analyzed.

\subsection{Political Changes}

The change of mayor in Barcelona had the major political impact on the development of the project due to the role of the City Council as project promoter as well as the fact that the municipal company 22 Arroba BCN SA was under public control. A change of mayor usually brought about a new vision and strategy for the city and this also influenced the priorities and development directions of 22@. During the period analyzed (2000-2018), Barcelona had four different mayors from three different parties:

- Clos (26 September 1997-8 September 2006), Socialists' Party of Catalonia;

- Hereu (8 September 2006-2 July 2011), Socialists' Party of Catalonia;

- $\quad$ Trias (2 July 2011-13 June 2015), Democratic Convergence of Catalonia;

- Colau (13 June 2015) Barcelona en Comú.

The Socialist party of Catalonia was well established in the City Council, governing the city of Barcelona from 1979 until 2011 and leading the rebirth of the city until its maximum expression during the Olympic Games in 1992 under the mayor Pasqual Maragall. The popularity of the Olympic Games contributed to the high level of popularity of the party, creating a continuity that helped to develop a vision and a strategy for the whole city. Political changes at the local level can be interpreted from two different perspectives: on the one hand the idea that candidates from the municipality needed to propose a new vision that could gather votes ahead of the city elections, and on the other hand, the idea of mayors of continuity and mayors of discontinuity. The continuity between Mayor Clos and Mayor Hereu was understandable since both came from the same party and Mayor Hereu worked with Mayor Clos when he was the mayor of the city. The 22@ project was born and started being implemented during the mandate of Mayor Clos, becoming his main legacy for the city. Once Mayor Hereu took power, he believed in the project of 22@, reaping to some extent the results of Mayor Clos' efforts with the maturity of the project.

After mayor Hereu, Xavier Trias became the new mayor of Barcelona in June 2011, the first mayor from a different political party since 1979. Mayor Trias can be viewed as a mayor of continuity, due to his strategy of applying the lessons learned from the 22@ experience to other development projects within the city. However, he could also be regarded as a mayor of discontinuity, due to his vision focused on a smart city, relegating 22@ to a secondary level of importance. During the first part of his mandate, Barcelona was suffering the consequences of the economic crisis and he had to follow the politics of austerity. Only in the second part of his mandate was he able to invest in the Smart city strategy. The 22@ was connected with the smart city strategy due to its ability to attract companies that were investing in smart technologies. The concept of "arrobizar" shows the continuity as well as changes of the project due to political dynamics. The idea was to transfer the lessons learned from the $22 @$ experience to other urban areas in order to increase economic activity in every district of the city, avoiding the concentration of all the activities in the 22@ area.

The election of Mayor Colau brought about an important discontinuity with the past local government administrations in Barcelona. Her vision and related priorities focused on social inequalities and the overall social aspects of city management, with a low priority given to increasing the city's 
competitiveness on a global scale. In 2017 a new municipal body was created (22@ Coordination Commission) in order to strengthen the relationship of the 22@ with the neighborhood, to increase local participation and to revive the urban transformation of the area. In fact, during the same years a participatory process called Re-think the 22@ was promoted, which aims to modify the strategy of the 22@ considering the new needs and challenges of the city. The new strategy presented in November 2018 is oriented towards sustainable and inclusive values, promoting more social housing units, a collaborative economy, the protection of industrial heritage, a new infrastructure plan and a modification of the zoning plan.

The aforementioned evolution of the district over 18 years has shown how the 22@ has adapted to the change of political agendas. The development of 22@ followed different pathways, which were influenced by variations in political priorities and development strategies at the city level. Moreover, some adaptive governance methods have facilitated this evolution from a political point of view, mainly the collaboration across actors, scales and levels promoted by bridging organizations with different characteristics and purposes, as well as community empowerment and engagement in participatory processes and consultations.

\subsection{Economic Changes}

The influence of economic factors in the development of the project have been relevant, also taking into account the dependence on the private sector for the physical transformation of the area and for stimulating economic activities. In particular, two important economic factors have affected the development of the project: the macroeconomic situation at the beginning of 2000, including Spain's membership in the Eurozone; and the Spanish property bubble (2008-2014) and the financial crisis (2008-2015). Considering these two events, the timing has been crucial as the project had sufficient time to evolve and be more resilient to the impact of the crisis. The entire process of transformation had a 20-year time frame, during which the arrival of new companies and the physical transformation would take place simultaneously. The crisis changed this plan producing the following dynamics, based on the requirements and capital of the private sector:

- $\quad$ Fewer companies were able to invest in new buildings;

- Many companies had to reduce the number of employees, reducing the need for new spaces;

- The overall economic uncertainty decreased investment plans;

- The lack of companies and investors influenced the overall development and level of urbanization of the area.

From a business development point of view, the crisis reduced the number of companies that moved into the district in comparison to previous years. Nevertheless, the district was able to attract new companies albeit at a decreasing rate of growth: for instance, between 2007 and 2008, 400 companies moved into the district, whereas between 2008 and 2009 there were only 61 new companies. It can be concluded that the crisis indeed slowed down the evolution of the project drastically. The impact of the crisis in the district was not as strong as in other sectors, especially due to the decision to attract knowledge-based activities; indeed, preliminary studies of the project analyzed and quantified the resistance of this sector in comparison to other sectors, concluding its higher resilience. The cluster strategy also reinforced the adaptation of the regeneration project during the crisis, as is shown by the creation of the design cluster. This cluster was created to reinforce the design tradition of Barcelona, doubling the effect on the 22@ brand: on the one hand, the people who already knew the 22@ project became aware of the strength of the design in Barcelona; and on the other hand, the 22@ project could rely on a new cluster, highly integrated with the Media and ICT clusters.

Political actors tried to counterbalance the negative impact of the financial crisis by adopting two different courses of actions, as exemplified by mayor Hereu and mayor Trias. The first in 2008 decided to invest public money in order to protect and stimulate the economic activity of the city, whereas the second adopted a strategy based on austerity, not only because of the higher investments 
implemented by the mayor Hereu but also because austerity was the strategy adopted at the national and European level. Another political decision, motivated by the financial crisis but also according to some stakeholders by political reasons, was the dismantling of the municipal company 22 Arroba BCN SA and the integration of its activities into their respective municipal departments. In addition to the strategy to transfer the lessons of 22@ to the entire city, the central government demanded to substantially reduce costs, which resulted in the dismantling of municipal companies that were created under positive economic conditions.

The financial crisis was a stress test for the project as it allowed verifying if the transformation process and the ideas behind the project were robust. From a financial point of view, the flexibility was important, since it was a gradual process, which transformed the district according to the private sector needs: when companies were growing, they needed additional space, and investment in new buildings could take place. When there was no need, the transformation slowed down. Companies were constantly moving to the district even during the crisis, since many constructions were built during the positive economic situation, leaving office spaces vacant waiting for demand and creating a stock of space for the coming years. Only in the middle of 2016 did this stock reached a low level, making it necessary to build new offices in order to keep the price per $\mathrm{m}^{2}$ under control. According to a sectoral study on the real estate market in the district, 50.6\% of the land of the 22@ district is still pending to be completely transformed. It is clear that transformation has been delayed, as the project is a 20-years project and the financial crisis is one of the explanations for this delay [30]. Two points prove this fact: by December 2010, 68.92\% of the land was approved to be transformed, whereas in December 2014, the percentage increased to $70.5 \%$ (+1.58 percentage points); regarding the 4600 social housing units expected, 1520 were already built in 2010, which increased to 1600 in December 2014 (+80 units) [30].

From an adaptive governance perspective, the lack of leadership after the dismantling of the municipal company slowed down the transformation process, but existence of a bridging organization has been seen as necessary, as is shown by the creation of the 22@ Coordination Commission in March 2017.

\subsection{Technological Changes}

The 22@ considers innovation as a key element of its entire system: finance, infrastructure, public services, regeneration and economic promotion. Innovation includes the concept of research and development, where companies and universities play an important role and have the capacity to create new markets and therefore new jobs. Innovation is the link between the technological aspects and 22@ goals: these aspects have shown a limited power of influence in comparison with the political and economic elements, mainly due to the public leadership of urban and economic regeneration projects, directly related to the other external factors. There are two specific elements whose impact could not be foreseen when the project was planned and that have completely changed the features of the district: the rise of smartphones, apps and e-commerce and smart technology. In fact, both elements have characterized the profile of the new companies and the strategy of the city in the last years.

The smartphones, the market and employment generated by the development of apps partially supported the economic goals of the district in terms of employment and creation of companies. Barcelona was already an attractive city for startups in general, where the agency of economic development Barcelona Activa promoted startup incubators and supported the generation of companies in the technology sector. The city council realized the importance of this sector, obtaining the GSMA (Global System Mobile Association) Mobile World Congress in 2006 and becoming since 2011 and until 2023 the GSMA Mobile World Capital [31]. Regarding the smart city strategy, this was the main vision and legacy of Mayor Trias in 2013, the new vision of making Barcelona a smart city acting as a reference. This strategy was a metropolitan strategy born outside the 22@ strategy, but the infrastructures and high-tech companies located in 22@ made 22@ the optimal place to develop the model. 
It was not possible to estimate the impact of these technologies on everyday life, but it was clear that it was important to promote the research and create new markets, giving the private sector and the market itself the optimal conditions to grow. A modern infrastructure system was crucial, which made the 22@ the best place in the city to test new smart technology related to phones and sensors. The Urban Lab (started in 2008) was the main project that connected technology and urban transformation. According to the website of 22@ project, the Urban Lab was "a tool to facilitate the use of public spaces in the city of Barcelona to carry out tests and pilot programs on products and services with an urban impact, which are in the premarket stage and in line with the Barcelona City Council's aims, priorities, and lines of action" [32]. It was a win-win situation for the public and the private sector: the private sector was allowed to test new technology cooperating with the city council, and every tested solution that works could be implemented to improve the quality of life and to create a new market and employment. With the promotion of a Smart City strategy through the entire city, the Urban Lab project was developed up to a certain level, and therefore the impact of technology on the transformation of the 22@ did not reach the magnitude of the impact of political and economic forces. In fact, the idea of the municipality was to reduce the singularity of the project by bringing its strategy to other districts of the city. This loss of priority also explains the lower impact of the technological aspect of the evolution of the regeneration project, since the area of action was expanded to the entire city. In terms of adaptive governance, the change of priorities from district to municipal shows how the governance system of the project was scaled up to the entire city in order to distribute the economic and innovative activity in the entire district.

A final aspect worth mentioning is the creation of the Center of Urban Innovation in a former industrial factory in the northern part of the 22@. This center will partner together with Cisco for the promotion of IoT (Internet of Things) and Smart City technologies. This public-private alliance will allow developing a project that will contribute to the growth of the existing innovation ecosystem of the city, stimulating startups, small and medium-sized businesses, involving citizens and universities in decision-making regarding the improvement of the urban habitat [33]. The technological aspects of the project regain importance in the development of the 22@ and although its impact is not comparable to the other external forces analyzed, it is relevant from a strategic point of view.

\section{Discussion}

The adaptive governance approach [21] uses the concepts of scales and levels [26] to illustrate how flexibility and interrelationships between different dimensions and components of the governance system are able to deal with the complexity and uncertainty related to complex dynamical processes such as urban regeneration. In the experience of 22@, it is possible to identify three different levels in a hierarchical structure:

- District: the level closer to the regeneration process in the Poblenou neighborhood;

- Metropolitan: the level that encompasses all the districts of the city of Barcelona and seeks to reconcile different priorities for the urban area as a whole;

- City network: the level that represents the economic global network of cities in which different urban areas are connected and compete with each other.

The three levels influence the 22@ regeneration project since the metropolitan level determines the priorities of the project in the context of the wider political agenda of the city of Barcelona and the city network level can shift the focus from citizen-oriented strategies to development approaches that give priority to competitiveness within a global context. The challenge for 22@ is therefore to reconcile the demands originating at the different levels. By way of illustration, the integration of the 22@ priorities within the metropolitan development strategy and with the wider smart city strategy sheds light on the need to reconcile divergent priorities. The evolution of the innovation district over the years and the pressures exercised by political, economic and technological factors have implied a shifting focus regarding the three levels identified [20]. These dynamics are consistent with an adaptive governance 
model where patters, trajectories and lessons learned are continuously negotiated and adjusted across sectors, issues and contexts [26].

The scales relevant to the analysis of the 22@ experience are related to the two dimensions of regeneration and innovation:

- Physical scale: this scale includes all aspects related to real estate development, the infrastructure system and industrial heritage preservation;

- Economic scale: this scale is based on the cluster strategy, generation of synergies, promotion of economic activity, and the attraction of investors, businesses and employees;

- Social scale: this scale considers the impact of the transformation on the local community.

Innovation and knowledge scale: this scale regards the knowledge-based economy strategy, the interaction between universities and businesses, the generation of startups, the creation of new products and services and the opening up of new market opportunities. Examples of cross-scale interactions are the integration of Urban Labs (economic and innovation) or the construction of social housing (physical and social). However, there are also instances of tensions and conflicting priorities between scales such as the needs to promote new economic activities and the related need for infrastructure interventions versus the protection of the existing industrial heritage. The framing of scales is not easily achieved and can be regarded as a strategic objective to be obtained through the so-called "politics of scale", which stresses that framing policy issues at different geographical and temporal levels involves strategic upscaling and downscaling based on shifting priorities [34].

The cross-level and cross-scale interactions require the creation of bridging organizations [23]. Figure 4 shows the positioning of the municipal company 22 Arroba BCN SA as a bridging organization in relation to the identified levels and scales. Since the establishment of 22 Arroba BCN SA there has been a strong link between the metropolitan and district level, since the company was created with the objective of operating in a specific district. The link has been reinforced at the in the initial phases of the project, since the CEO of the 22 Arroba BCN SA was also the planning manager of the City Council of Barcelona, ensuring an alignment between both levels.

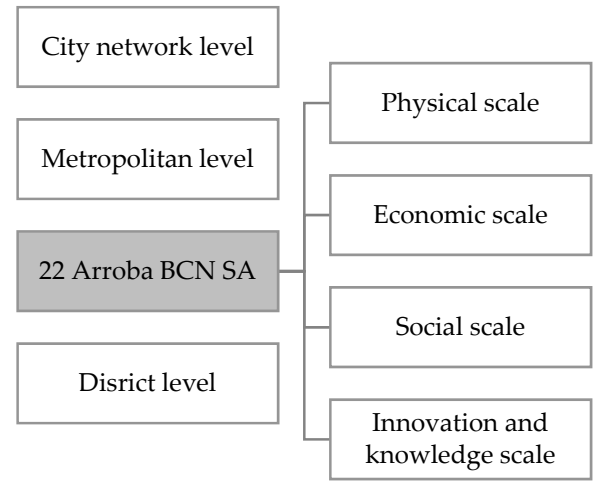

Figure 4. Arroba BCN SA as a bridging organization.

The Barcelona regeneration model and the organizational structure of the 22@ are significant in order to identify actions for adaptive governance systems. While anticipation does not suit urban realities based on complex systems with actions, interests and consequences difficult to forecast, the actions of learning and adaptations are easier to recognize. Learning is a feasible as well as necessary action and is easy to implement, and the policies and strategies applied can be monitored, evaluated and modified whenever needed. The 22@ project could not have been possible without the learning process derived from the organization of the Olympic Games in 1992. Adaptation in the organizational structure is explicit considering how it was possible to keep developing the project after the dismantling of the municipal company 22 Arroba BCN SA. In fact, after it was dismantled, the 22@ Network was responsible for some tasks regarding the economic development of the area until the new public 
institution (i.e., the 22@ Coordination Commission) was created in order to restore the public leadership of the project.

\section{Conclusions}

Within the context of complex dynamics related to political, economic and technological changes, the development trajectory of the 22@ innovation district has been characterized by a high level of resilience and adaptability, which is typical of an adaptive governance approach. This can be explained on the basis of the following processes, which have characterized the development of the innovation district and have allowed it to continuously transform and respond to exogenous factors:

- Dynamic physical transformation according to investor availability;

- Modification of transformation dynamics (from investment and then clients to clients and then investment);

- Sensibility to opportunities and actors available for potential projects;

- Integration of the project goals to the district reality (brownfield situation);

- Creation of new economic activities aligned with global trends and future developments;

- Inclusion of the city's overall needs into the project at the district level;

- Effective coordination of stakeholders at different scales and levels;

- Selection of clusters according to existing city assets;

- Adaptation of project goals to different political agendas.

The interplay of all of these factors and elements has ensured the 22@ project's successful transformation over the years. This appears to be a key element of urban regeneration projects taking place in complex environments characterized by continually changing external conditions. From a political point of view, the agenda of each government adapted itself to the situation of the city and the ongoing projects related to the strategic plan at the city level, but at the same time the strategic plan was modified according to the political agendas of each government. The 22@ project has evolved following some pre-established goals, which were adapted based on the local government's vision, which in turn was adapted in light of the existing assets and advantages of the city. This evolution can be considered as a dynamic form of adaptability characterized by constant feedback mechanisms. An adaptive system needs an adaptive governance as the governance systems needs to be able to deal effectively and efficiently with all forms of flexibility, complexity and uncertainty. The 22@ project started within the context of a positive macroeconomic situation (Spanish membership in the Eurozone) and was able to achieve a certain level maturity once the situation worsened (financial, real estate and national debt crisis). During the 2013-2014 period, Barcelona started to recover from the crisis, generating employment and increasing real investments into strategic sectors and infrastructures. The lack of investors and new constructions led to an increase in the value of residential and commercial properties, thereby creating additional challenges for the development of the project. The technological aspects have a less relevant impact on the dynamic evolution of 22@ compared to the political and economic aspects, since they were not directly related to the management or the funding of the project. It should also be emphasized that the development and evolution of 22@ benefited from its integration within the smart city strategy of Barcelona. The Urban Lab experiment started in 22@ and was implemented in other parts of the city, together with the Mobile World Congress and the consequent growth of the apps market, which has consequently modified the businesses activities of the district.

All of these dynamics show the capacity of the 22@ innovation district to learn and adapt within a context characterized by continuous change and uncertainty and, in particular, to combine different sources of knowledge and expertise from actors and stakeholders as a key source of learning to adapt. The concept of learning is an essential element of adaptive governance since it is important to analyze and understand how the system works and how it can change before deciding on any adaptive strategy. This learning process has to be nurtured by all actors and stakeholders involved even if, as the experience of 22@ clearly shows, the role of a bridging organization can certainly facilitate it 
by acting as a mediating agency within a complex web of actors and stakeholders. Even if adaptive governance calls for a high level of flexibility, a certain degree of steering is necessary to manage change and uncertainty.

The article has illustrated the importance of adaptive governance not only as an analytical framework that allows to interpret and shed light on urban regeneration processes, but also as a normative framework which can guide and support local decision-makers in the management and coordination of complex projects and urban transformations. This dual nature of adaptive governance makes it a very relevant and flexible approach that can be applied in different contexts characterized by a diversity of institutional and organizational settings. Even though the experience of 22@ is in many respects unique, not least because of the particular socio-economic milieu in which it originated, various lessons can be learned from it and these may be relevant to the development of innovation districts in other urban areas. In particular, with reference to adaptive governance as an approach to the steering of development processes in the context of dynamic uncertainty, it appears that the relevance of "bridging organizations" cannot be underestimated. The key question becomes whether these organizations should be actively nurtured and supported by public institutions or whether they should be allowed to develop organically from the bottom up. Without generalizing, a mixed approach seems to be preferable with support provided in the initial stages of development followed by an increased degree of operational and strategic independence. Only in this way does it appear possible to ensure the effective and efficient integration and coordination of the multiple dimensions that are typical of highly dynamic innovation districts, which seek to combine physical, economic and social urban development.

Author Contributions: Conceptualization, A.G. and R.P.H.; methodology, R.P.H. and A.G.; formal analysis, R.P.H., writing —original draft preparation, R.P.H. and A.G.; writing—review and editing, A.G. and R.P.H. All authors have read and agreed to the published version of the manuscript.

Funding: This research received no external funding.

Conflicts of Interest: The authors declare no conflict of interest.

\section{Appendix A}

\section{Interviews Guidelines}

\section{Background}

- What was your involvement in the project?

- In which period were you involved in the project?

- What is your general opinion about the project?

- Which factors were in your opinion instrumental in relation to the general project performance?

\section{Political factors}

- Over approximately 15 years of the project, there have been different mayors in Barcelona with different ideas about the 22@ (Clos from 26 September 1997 to 8 September 2006, Hereu from 8 September 2006 to 2 July 2011, Trias from 2 July 2011 to 13 June 2015 and Colau from 13 June 2015). Broadly speaking, in your opinion which specific powers did each mayor have to influence the development of the project? What was the level of involvement of each mayor? Could you summarize the positions, that according to you, each mayor has taken in regards the project?

- What was the level of autonomy and power given to the municipal company 22 ARROBA BCN S.A. by each mayor?

- $\quad$ The 22@ district has promoted the policy to facilitate the concentration of companies and research centers. Is this still a priority? Has a similar approach been implemented in other areas of the city? Who has driven such initiatives? Could you provide examples? 
- What is the specific position of 22@ within the "triangle of centralitat" (area of economic development involving different city areas)?

- The project tries to regenerate and transform the area with a possible tension between the past and the future. Which measures have been taken in different stages of development to safeguard the historical heritage? How has a balance between innovation and regeneration been achieved? How have conflicts been managed?

- The Barcelona model in the field of urban regeneration is characterized by a high level of citizen participation. What role has been given to the inhabitants of the district in the decision-making process? What relationship has been maintained with the 'Associació de Veïns i Veïnes del Poblenou'?

- Considering the different documents that form the 22@ Barcelona plan (Modification of the Municipal General Plan (MPGM), Special Infrastructure Plan (PEI), Modification of the Special Plan of Architectural Historic-Artistic Heritage sites of the city of Barcelona), which powers did the city council have in each phase of the project to adapt these? What was the position of the city council regarding these documents?

- The project has been characterized by a high level of flexibility. What have been the advantages and disadvantages? Could you please provide concrete examples?

\section{Economic factors}

- How has the project been financed? Which funding sources have been used? What has been the role of value capture financing?

- What has been the relationship between the public and private sectors in terms of financing the project? How has the relationship evolved over the years? How has the real estate and financial crisis affected the project? How did the project react to such crises? (e.g., alternative financing, reduction of project activities)? Have there been other financial or macroeconomic factors that have affected the development of the project?

- The international promotion of the neighborhood has managed to attract foreign businesses and investors. Which strategies have been followed to attract international companies? How about financial incentives also for local businesses?

- Considering startups and the technological incubators, how was their relationship with larger businesses and with the academic sector?

- Has there been an explicit attempt to promote clusters? Has the attempt been successful? What have the advantages and disadvantages of cluster creation been? Have the different clusters generated synergies?

- What has the relationship of the project with the building sector and private developers been?

- Has the project been successful in generating local employment? Have local businesses and universities played an active role in training provision to reduce local unemployment? Has the project attracted foreign workers?

- What has the role of technological innovation in the district in terms of promotion of the smart city discourse been?

\section{Technological factors}

- What has the effect of the ongoing technological innovations (e.g., big data, smartphones, sensors, IoT, 3D printers) been on the development of the project? What role did the 22 ARROBA BCN SA have in this process?

- Have the technological innovations changed the way of operating of the public sector involved with the development of 22@? To what extent has the public sector in the district been a beneficiary of technological innovations? 
- Technological advances and the principle of sustainability have driven research and the creation of green infrastructure in the district. To what extent has this influenced the development of 22@, for example in terms of renewable energy, pneumatic waste collection and environmental sensors?

- What has the role of cooperation between the public, private and academic sector been in term of promotion of technological innovation in the district? What have the key facilitating and constraining factors been?

\section{Adaptive processes}

- The company 22 ARROBA BCNSA has functioned as a "bridging organization" in the development of the project. Could you explain how the company reacted to the changes that have been mentioned above?

- During the adaptive process it is important to learn and, if needed, change the course of action. How did the company 22 ARROBA BCN SA achieve this? How did the company relate to all local stakeholders and decision-makers? How did the company mange conflicts and overcome stumbling blocks?

- Flexibility has been a key characteristic of the urban restructuring of 22@ (dynamic management of the territory, open time frames). What other elements have characterized the flexibility of 22@? What have the positive and negative aspects of this approach been? What have the lessons learned been? To what extent can these by applied to different contexts?

- The company 22 ARROBA BCN SA has streamlined the process of decision-making thorough autonomous powers and responsibilities. Has this happened to the detriment of accountability and transparency?

- $\quad$ Adaptive processes may benefit from making use of local knowledge. Has this happened during the different phases of development? Which relationships were established between the company 22 ARROBA BCN SA and organized and non-organized citizens? To what extent have they improved the adaptive capacity of the development process?

\section{References}

1. Zheng, H.W.; Shen, G.Q.; Wang, H. A review of recent studies on sustainable urban renewal. Habitat Int. 2014, 41, 272-279. [CrossRef]

2. Ganser, R. Monitoring brownfield housing development: Strengths and weaknesses of indicator based monitoring in the English planning system. J. Environ. Plan. Manag. 2008, 51, 201-220. [CrossRef]

3. Robert, P.; Sykes, H. Urban Regeneration: A Handbook; Sage Publications: Thousand Oaks, CA, USA, 2000.

4. Lovering, J. The relationship between urban regeneration and neoliberalism: Two presumptuous theories and a research agenda. Int. Plan. Stud. 2007, 12, 343-366. [CrossRef]

5. Cosgrave, E.; Arbuthnot, K.; Tryfonas, T. Living labs, innovation districts and information marketplaces: A systems approach for smart cities. Procedia Comput. Sci. 2013, 16, 668-677. [CrossRef]

6. Trullén, J. El proyecto Barceona-Ciudad del Conocimiento desde la economía. In Política Industrial y Tecnológica II; Mosconi, F., Sole-Parellada, F., Chantiri-Zamudio, A., Eds.; Edicions de la Universitat Politécnica de Catalunya: Barcelona, Spain, 2001; pp. 111-124.

7. Katz, B.; Wagner, J. The Rise of Innovation Districts: A New Geography of Innovation in America; Brookings Institution-Metropolitan Policy Program: Washington, DC, USA, 2014.

8. Morgan, K. The exaggerated death of geography: Learning, proximity and territorial innovation systems. J. Econ. Geogr. 2004, 4, 3-21. [CrossRef]

9. Pyke, F.; Becattini, G.; Sengenberger, W. Industrial Districts and Inter-Firm Co-Operation in Italy; International Institute for Labour Studies: Geneva, Switzerland, 1990.

10. Piore, M.; Sabel, C. The Second Industrial Divide: Possibilities for Prosperity; Basic Books: New York, NY, USA, 1984.

11. Muller, E.K.; Groves, P.A. The emergence of industrial districts in mid-nineteenth century Baltimore. Geogr. Rev. 1979, 69, 159-178. [CrossRef] 
12. Russell, M.G.; Moss, D.J. Science parks and economic development. Interdiscip. Sci. Rev. 1989, 14, 54-63. [CrossRef]

13. Etzkowitz, H.; Leydesdorff, L. The dynamics of innovation: From National Systems and "Mode 2" to a Triple Helix of university-industry-government relations. Res. Policy 2000, 29, 109-123. [CrossRef]

14. Arnkil, R.; Järvensivu, A.; Koski, P.; Piirainen, T. Exploring the Quadruple Helix: Outlining user-oriented innovation models. Available online: https://trepo.tuni.fi/bitstream/handle/10024/65758/978-951-44-8209-0. pdf? sequence $=1 \&$ is Allowed =y (accessed on 4 August 2019).

15. Van Dijk, M.P. Flexible specialisation, the new competition and industrial districts. Small Bus. Econ. 1995, 7, 15-27. [CrossRef]

16. Morisson, A. Innovation Districts: A Toolkit for Urban Leaders; Arnault Morisson: Lexington, KY, USA, 2015.

17. Hughey, A.W. Class Distinctions for the Global Economy. Available online: https://digitalcommons.wku. edu/cgi/viewcontent.cgi?article=1020\&context=csa_fac_pub (accessed on 18 July 2019).

18. Florida, R. The Rise of the Creative Class; Basic Books: New York, NY, USA, 2004.

19. Lemos, M.C.; Agrawal, A. Environmental governance. Annu. Rev. Environ. Resour. 2006, 31, 297. [CrossRef]

20. Giezen, M.; Bertolini, L.; Salet, W. Adaptive capacity within a mega project: A case study on planning and decision-making in the face of complexity. Eur. Plan. Stud. 2015, 23, 999-1018. [CrossRef]

21. Janssen, M.; van der Voort, H. Adaptive governance: Towards a stable, accountable and responsive government. Gov. Inf. Q. 2016, 33, 1-5. [CrossRef]

22. Termeer, C.J.; Dewulf, A.; Lieshout, M. Disentangling scale approaches in governance research: Comparing monocentric, multilevel, and adaptive governance. Ecol. Soc. 2010, 15, 29. [CrossRef]

23. Folke, C.; Hahn, T.; Olsson, P.; Norberg, J. Adaptive governance of social-ecological systems. Annu. Rev. Environ. Resour. 2005, 30, 441-473. [CrossRef]

24. Chan, S. Complex Adaptive Systems. Available online: http://web.mit.edu/esd.83/www/notebook/Complex\% 20Adaptive\%20Systems.pdf (accessed on 18 June 2019).

25. Holland, J.H. Complex adaptive systems. Daedalus 1992, 121, 17-30.

26. Sharma-Wallace, L.; Velarde, S.J.; Wreford, A. Adaptive governance good practice: Show me the evidence. J. Environ. Manag. 2018, 222, 174-184. [CrossRef] [PubMed]

27. Verschuren, P.; Doorewaard, H. Research strategies. In Designing a Research Project; Eleven International Publishing: The Hague, The Netherlands, 2010; pp. 155-201.

28. Trullén, J. La metròpoli de Barcelona cap a l'economia del coneixement: Aglomeració central i arc tecnològic 2002. Databases 2000, 1999, 1985.

29. Blanco, I. Does a 'Barcelona model'really exist? Periods, territories and actors in the process of urban transformation. Local Gov. Stud. 2009, 35, 355-369. [CrossRef]

30. de Barcelona, A. 10 Anys de 22@: El Districte de la Innovació; Ajuntament de Barcelona: Barcelona, Spain, 2016.

31. Barcelona Activa. Who We Are. 2011. Available online: http://www.barcelonactiva.cat/barcelonactiva/en/allabout-barcelona-activa/who-we-are/ (accessed on 12 November 2016).

32. 22 Arroba BCN. Economic Innovation: Barcelona Urban Lab. 2011. Available online: http://www.22barcelona. com/content/view/698/897/lang,en/ (accessed on 20 December 2016).

33. Ajuntament de Barcelona. Finalitzen les Obres a Ca l'Alier, el Nou Centre d'Innovació Urbana de Barcelona. 2018. Available online: http://ajuntament.barcelona.cat/premsa/2018/06/07/finalitzen-les-obres-a-ca-lalier-elnou-centre-dinnovacio-urbana-de-barcelona/ (accessed on 22 November 2018).

34. Olsson, P.; Folke, C.; Galaz, V.; Hahn, T. Enhancing the fit through adaptive comanagement: Creating and maintaining bridging functions for matching scales in the Kristianstads Vattenrike Biosphere Reserve Sweden. Ecol. Soc. 2007, 12, 28. [CrossRef]

(C) 2020 by the authors. Licensee MDPI, Basel, Switzerland. This article is an open access article distributed under the terms and conditions of the Creative Commons Attribution (CC BY) license (http://creativecommons.org/licenses/by/4.0/). 